\title{
Echinostoma aegyptica (Trematoda: Echinostomatidae) Infection in Five Riparian People in Savannakhet Province, Lao PDR
}

\author{
Jong-Yil Chai ${ }^{1,2, *}$, Bong-Kwang Jung ${ }^{1}$, Taehee Chang', Hyejoo Shin', Woon-Mok Sohn ${ }^{3}$, Keeseon S. Eom4, \\ Tai-Soon Yong ${ }^{5}$, Duk-Young Min ${ }^{6}$, Bounlay Phammasack ${ }^{7}$, Bounnaloth Insisiengmay ${ }^{7}$, Han-Jong Rim ${ }^{8}$ \\ IInstitute of Parasitic Diseases, Korea Association of Health Promotion, Seoul 07649, Korea; ' 2 Department of Tropical Medicine and Parasitology, \\ Seoul National University College of Medicine, Seoul 03080, Korea; ${ }^{3}$ Department of Parasitology and Tropical Medicine, and Institute of Health \\ Sciences, Gyeongsang National University College of Medicine, Jinju 52727, Korea; ' $\mathrm{D}$ Department of Parasitology and Parasite Research Center, \\ Parasite Resource Bank, Chungbuk National University School of Medicine, Cheongju 28644, Korea; ${ }^{5}$ Department of Environmental Medical \\ Biology, Institute of Tropical Medicine and Arthropods of Medical Importance Resource Bank, Yonsei University College of Medicine, Seoul 03722,

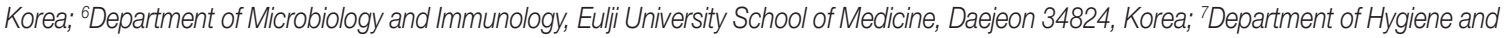 \\ Prevention, Ministry of Health, Vientiane, Lao PDR; ${ }^{8}$ Department of Parasitology, Korea University College of Medicine, Seoul 02841, Korea
}

\begin{abstract}
Human infection with Echinostoma aegyptica Khalil and Abaza, 1924 (Trematoda: Echinostomatidae) is extremely rare. In this study, we confirmed E. aegyptica infection in 5 riparian residents living along the Mekong River in Savannakhet Province, Lao PDR. The patients revealed eggs of Opisthorchis viverrini/minute intestinal flukes, echinostomes, and other parasites in fecal examinations using the Kato-Katz technique. Following treatment with praziquantel 30-40 $\mathrm{mg} / \mathrm{kg}$ and pyrantel pamoate $10-15 \mathrm{mg} / \mathrm{kg}$ in a single dose and purging with magnesium salts, adult specimens of various helminth species were collected. Among the trematodes, echinostome flukes of 4.5-7.6 mm in length $(n=134$; av. 22.3 specimens per case) were of taxonomic interest and subjected in this study. The flukes were morphologically characterized by having total $43-45$ collar spines arranged in 2 alternating rows (corner spines usually 5 on each side) and compatible with previous descriptions of $E$. aegyptica. The patients were mixed-infected with other helminths, so specific clinical manifestations due to this echinostome fluke were difficult to determine. The present paper describes for the first time human E. aegyptica infections in Lao PDR. This is the second report of human infection (2nd-6th cases) with E. aegyptica in the world following the first one from China.
\end{abstract}

Key words: Echinostoma aegyptica, echinostome, Savannakhet, Lao PDR

Zoonotic minute intestinal flukes, including heterophyids (Heterophyidae) and lecithodendriid-like flukes (Lecithodendriids and Phaneropsolidae), are generally not so harmful to humans unless the patient is heavily infected or immunocompromised $[1,2]$. However, large-sized intestinal flukes, in particular, echinostomes (Echinostomatidae), can cause significant gastrointestinal symptoms that include epigastric or abdominal pain accompanied by diarrhea, easy fatigue, malnutrition, and occasionally ulcer and bleeding [2,3]. Total 23 species worldwide have been reported as zoonotic echino-

- Received 1 September 2019, revised 11 October 2019, accepted 11 October 2019. *Corresponding author (cjy@snu.ac.kr)

(c) 2020, Korean Society for Parasitology and Tropical Medicine

This is an Open Access article distributed under the terms of the Creative Commons Attribution Non-Commercial License (https://creativecommons.org/licenses/by-nc/4.0) which permits unrestricted non-commercial use, distribution, and reproduction in any medium, provided the original work is properly cited. stomes; they belong to Echinostoma (8 species), Isthmiophora (2 species), Echinochasmus (6 species), Acanthoparyphium (1 species), Artyfechinostomum (3 species), Echinoparyphium (1 species), Himasthla (1 species), and Hypoderaeum (1 species) [2,3].

Lao People's Democratic Republic (Lao PDR) is a country where foodborne parasites, in particular, liver fluke (Opisthorchis viverrini) and intestinal flukes (Haplorchis taichui, H. pumilio, H. yokogawai, Phaneropsolus bonnei, and Caprimolgorchis molenkampi), are common according to the traditional food custom of eating raw or improperly cooked fish [4-9]. With regard to echinostome flukes, 4 reports have been available so far. In 2009, Sayasone et al. [10] reported 3 human infections with Echinochasmus japonicus in Savannakhet Province. After then, Chai et al. [11] detected 9 human cases infected with several species of echinostomes, including Echinostoma revolutum, Artyfechinostomum malayanum, Echinochasmus japonicus, and Eu- 
paryphium sp., in Khammouane Province. Later, Chai et al. [12] added 2 residents infected with Echinostoma ilocanum in Savannakhet Province. More recently, 11 riparian people in Khammouane Province were found to be infected with Echinochasmus caninus (syn. Episthmium caninum) [13].

During 2000-2004 and 2007-2011, the Korea Association of Health Promotion (KAHP), Seoul, Korea, and the Department of Hygiene and Prevention (DHP), Ministry of Health, Lao PDR conducted collaborative projects for intestinal helminthiases control in several provinces of Lao PDR. Fecal surveys were performed using the Kato-Katz technique on riparian residents in 6 localities of Savannakhet Province (Houay South, Houay North, Nang Soung, Xok, Songkhone, and Champhone). The results revealed that the residents were positive for various kinds of helminth eggs, which included the eggs of Opisthorchis viverrini/minute intestinal flukes, echinostomes, hookworms, Trichuris trichiura, and Taenia spp. [6]. We tried to collect the adult helminths after anthelmintic treatment and purging. Among the helminth species recovered, the present paper deals with Echinostoma aegyptica infection which was confirmed in 5 residents.

E. aegyptica was originally described from the intestine of a rat in Egypt in 1924 [14]. In 1939, Yamaguti [15] redescribed this species based on experimentally obtained specimens from rats in Japan. Human infection with this echinostome was reported only 1 time in China; 12 adult specimens were recovered after anthelmintic treatment of a 32-year-old female patient from Fujian Province in 2004 [16,17]. Thus, the present 5 cases mark the 2nd-6th human cases of E. aegyptica infection among the available literature.

The egg-positive cases of $O$. viverrini/minute intestinal flukes or echinostomes were given single oral doses of $30-40 \mathrm{mg} / \mathrm{kg}$ praziquantel (Shinpoong Pharm. Co., Seoul, Korea) and 1015 mg/kg pyrantel pamoate (Hangzhou Minsheng Pharm.
Group, Hangzhou, China) and purged with 30-40 $\mathrm{g} \mathrm{MgSO}_{4}$ an hour later. Adult helminths, including flukes, were collected from the diarrheic stools and washed several times in water. The flukes were fixed in 10\% formalin under a cover slip pressure, stained with Semichon's acetocarmine, and observed using a light microscope. Fecal examination of the riparian residents and worm recovery were officially approved by the Ministry of Health, Lao PDR based on the agreement between KAHP, Korea and DHP, Lao PDR. Informed consent was obtained from each person.

A total of 134 specimens of E. aegyptica were recovered from 5 residents (Table 1). The infected residents were $40-55$ years of age, consisting of 3 males and 2 females; the worm load was relatively low or moderate, from 1 to 47 per case (av. 22.3 specimens per individual). Some patients complained of clinical symptoms such as epigastric pain, abdominal discomfort, indigestion, and lethargy. However, they were co-infected with other trematodes, such as O. viverrini, Haplorchis spp., and lecithodendriid-like flukes (Caprimolgorchis molenkampi and Phaneropsolus bonnei) (partly reported in [6]). Therefore, specific symptoms due to E. aegytpica infection was difficult to determine.

Adult flukes of E. aegyptica were elongated leaf-like with slightly attenuated both ends (Fig. 1A, B). The body was 6.0 (4.5-7.6) $\mathrm{mm}$ long and $1.1(0.8-1.8) \mathrm{mm}$ wide $(\mathrm{n}=16)$ (Table 2). The anterior end showed characteristic features of an echinostome, being equipped with a head collar and collar spines around the oral sucker (Fig. 1C, D). The number of collar spines was 43-45 in total, with 4-5 (usually 5) corner spines on each side, and dorsal spines arranged in 2 alternating rows (Fig. 1C, D). The collar spines were relatively long (0.030$0.048 \mathrm{~mm}$ ) and broad (1/3 of the length) but not sharply pointed (Fig. 1C, D). The oral sucker was small and about $1 / 3$ of the size of the ventral sucker. The cirrus sac containing the

Table 1. Collection of Echinostoma aegyptica specimens from riparian people in Savannakhet province, Lao PDR

\begin{tabular}{lccc}
\hline Villager serial No. $^{\text {a }}$ & Age \& gender & Year surveyed & No. of specimens collected \\
\hline 1 & $40 \mathrm{M}$ & 2008 & 2002 \\
2 & $53 \mathrm{M}$ & 2008 & 34 \\
3 & $45 \mathrm{~F}$ & 2008 & 22 \\
4 & $47 \mathrm{~F}$ & 2008 & 1 \\
5 & $55 \mathrm{M}$ & & 134 \\
\hline
\end{tabular}

aSome villagers complained of gastrointestinal symptoms of variable degrees, including abdominal pain, epigastric pain, indigestion, and diarrhea; however, their majority were mixed-infected with other helminths including Opisthorchis viverrini, Haplorchis spp., lecithodendriid-like flukes, Echinostoma ilocanum, hookworms, Trichostrongylus sp., Enterobius vermicularis, and Taenia sp. (Chai et al., 2007, 2018). 

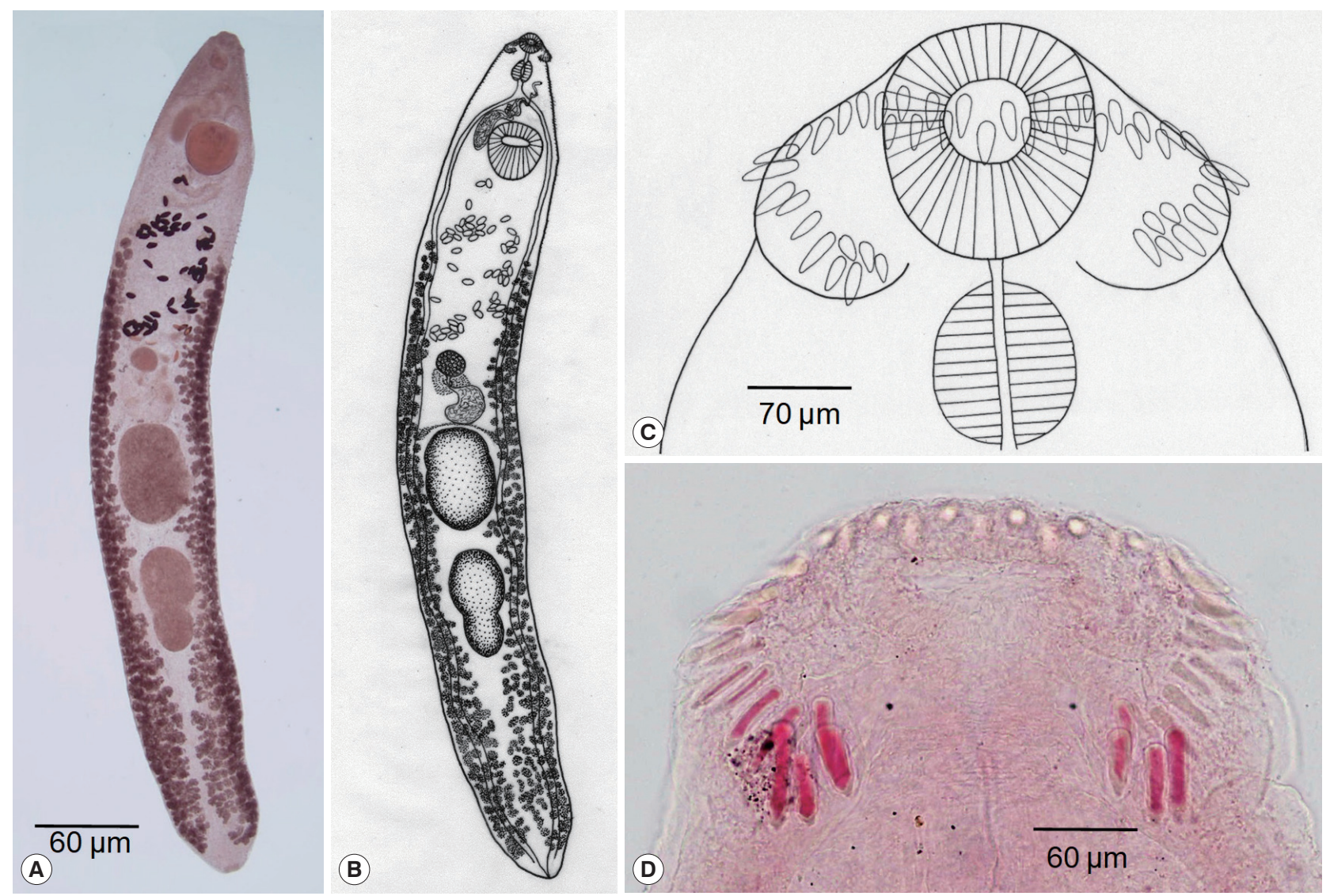

Fig. 1. Adult Echinostoma aegyptica collected from a riparian resident in Savannakhet Province, Lao PDR. (A) E. aegyptica specimen (6.0 mm long and $1.0 \mathrm{~mm}$ wide) showing its characteristic features for differentiation from other species of Echinostoma, i.e., the distribution of the vitellaria only from the level of some distance posterior to the ventral sucker to the posterior end of the body. The shape of the head collar, cirrus sac with a protruded cirrus, position of the ovary, and 2 tandem testes with median constrictions on both sides are also characteristic features for this species. Semichon's acetocarmine stained. (B) Line drawing of the specimen in Fig. 1A. (C) Line drawing of the head collar of a worm bearing 45 collar spines arranged in 2 alternating rows, with 5 corner spines on each side. (D) Close-up view of the head collar and collar spines in a worm showing the arrangement of the collar spines.

Table 2. Measurements of Echinostoma aegyptica adult specimens collected from riparian people in Savannakhet Province, Lao PDR in comparison with those in a previous report

\begin{tabular}{|c|c|c|}
\hline \multirow{2}{*}{ Item } & \multicolumn{2}{|c|}{ Measurements in mm } \\
\hline & Present study ( $n=16)$ (mean) & Yamaguti [15] (n=12) \\
\hline Body & $4.50-7.57(6.03) \times 0.80-1.80(1.09)$ & $5.60-7.25 \times 0.65-1.05$ \\
\hline Head collar & $0.167-0.299(0.189) \times 0.207-0.404(0.321)$ & $0.20-0.38$ (breadth) \\
\hline No. collar spines & $43-45$ & $43-45$ \\
\hline No. corner spines & 5 (rarely 4) & 5 (rarely 4) \\
\hline Oral sucker & $0.125-0.195(0.162) \times 0.122-0.205(0.172)$ & $0.140-0.175 \times 0.130-0.225$ \\
\hline Prepharynx (length) & $0.036-0.073(0.050)$ & $0.020-0.075$ \\
\hline Pharynx & $0.120-0.234(0.152) \times 0.113-0.178(0.149)$ & $0.126-0.188 \times 0.126-0.150$ \\
\hline Esophagus (length) & $0.228-0.508(0.348)$ & $\begin{array}{c}.1200 .100 \times 0.1200 \\
-\end{array}$ \\
\hline Cirrus sac & $0.388-0.642(0.444) \times 0.116-0.265(0.205)$ & $0.30-0.55 \times 0.18-0.20$ \\
\hline Ventral sucker & $0.412-0.630(0.498) \times 0.392-0.573(0.464)$ & $0.438-0.520$ (diameter) \\
\hline Ovary & $0.173-0.359(0.241) \times 0.153-0.328(0.228)$ & $0.220-0.330 \times 0.188-0.275$ \\
\hline Anterior testes & $0.405-0.917(0.665) \times 0.332-0.642(0.452)$ & $0.710-0.950 \times 0.350-0.470$ \\
\hline Posterior testes & $0.402-0.951(0.702) \times 0.321-0.558(0.389)$ & $0.770-1.00 \times 0.280-0.420$ \\
\hline No. of uterine eggs & Numerous $(>120)$ & Numerous \\
\hline Size of eggs & $0.085-0.110(0.096) \times 0.044-0.062(0.054)^{a}$ & $0.096-0.123 \times 0.057-0.069^{b}$ \\
\hline
\end{tabular}

aEggs were measured in uteri of worms after staining, whereas these eggs ${ }^{b}$ were measured in life [15]. 


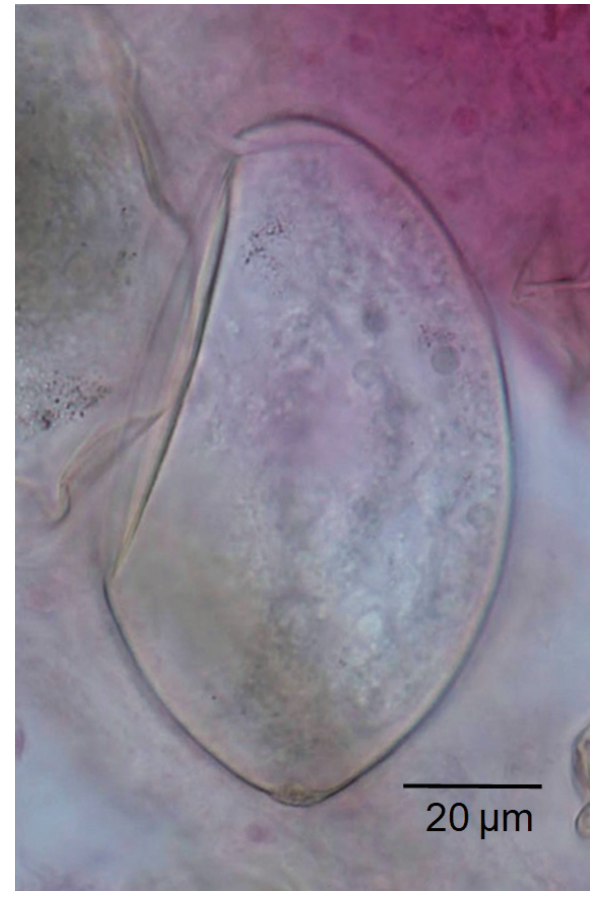

Fig. 2. Egg of Echinostoma aegyptica in the uterus of an adult worm collected from a resident after treatment with praziquantel and purging. Acetocarmine stain. The operculum of the egg is apparently seen, and the abopercular knob looks like a small wrinkle.

seminal vesicle, ejaculatory duct, and a long cirrus was located near the anterior half level of the ventral sucker but sometimes passed beyond the middle level of the ventral sucker. The uterine tubule was long and slender with a large number of eggs, up to a hundred per specimen. The ovary was round and median. The distribution of vitelline follicles was extensive; they extended laterally forming 2 lateral groups, from the level some distance posterior to the ventral sucker to near the posterior extremity. The 2 groups of vitellaria frequently merged near the posterior end of the body. Two elliptical testes were located tandem in the posterior field of the body often with more or less constricted lateral margins on each side. The eggs in feces or in the worm uterus (Fig. 2) were large and oval, with a relatively narrow operculum and a tiny abopercular wrinkle at the abopercular end; they measured 96 (85-110) $\mu \mathrm{m}$ long and 54 (44-62) $\mu \mathrm{m}$ wide $(\mathrm{n}=20)$. All these morphological characters were compatible with previous descriptions of E. aegyptica [14,15].

Echinostome species that have 43 or 45 collar spines and need differential diagnosis with E. aegyptica include at least 13 species; 1 Echinostoma spp. (E. macrorchis), 3 Euparyphium spp. (E. murinum, E. paramurinum, and E. albuferensis), 7 Echinopa- ryphium spp. (E. recurvatum, E. elegans, E. baculoides, E. ellisi, E. mordwilkoi, E. ralphaudyi, and E. hydromyos), and 2 Artyfechinostomum spp. (A. malayanum and A. sufrartyfex) [2]. Flukes of Echinoparyphium spp. and Euparyphium spp. have very short to short uterus with few loops and only a small number of eggs, which is a useful key to differentiate from our specimens which have a long uterus with many loops and numerous eggs that corresponded well to Echinostoma [18]. Artyfechinostomum spp. could be differentiated from our specimens by having deeply branched testes in the former [18]. E. macrorchis was morphologically the closest species with our specimens. However, E. macrorchis has larger testes with irregular margins $[19,20]$, whereas our specimens have smaller testes with smooth margins. The distribution of vitelline follicles is more extensive in E. macrorchis than in our specimens. Nucleotide data on E. macrorchis and E. aegyptica are not available in GenBank, and studies on this aspect are urgently needed.

After E. aegyptica (original name E. aegyptiaca) was first described in Egypt [14], Azim [21] was of opinion that E. aegyptica is a synonym of Echinoparyphium recurvatum. However, this synonymy was denied by Yamaguti [22]. Meanwhile, Yamaguti [15] redescribed this echinostome from Japan and used the name $E$. aegyptiacum. Later, the presence of this echinostome has been reported from rats in Taiwan [23], Vietnam [24], and Turkey $[25]$, and a human in China $[16,17]$. For the name of this echinostome, 3 slightly different names, E. aegyptiacum [23], E. aegyptica $[16,17,24,26]$, and E. aegyptiaca [25], have been used by different authors. In our study, we followed the name E. aegyptica largely because of convenience (shorter name).

Unfortunately, the life cycle of E. aegyptica has never been elucidated; thus, in our cases, the source of infection remains unclear. It is likely that freshwater snails or fish may have the metacercarial stage. Studies on the life cycle of E. aegyptica should be performed in the near future in Lao PDR or in other countries.

Based on this study and also on previous reports, it is suggested that various zoonotic echinostomes are widely distributed in Lao PDR [10-13]. They are at least 7 species, including E. revolutum, E. ilocanum, E. aegyptica, A. malayanum, E. japonicus, E. caninus, and Euparyphium sp., and the localities were Khammouane [11,13] and Savannakhet Province [10,12, this study]. Further studies to find out other echinostome species and other endemic localities should be performed.

Conclusively, the present study demonstrated for the first time the presence of human E. aegyptica infections in Lao PDR. 
This is the second report following the first one on human infection with this fluke in China.

\section{ACKNOWLEDGMENTS}

We thank the staff of the Center for Laboratory and Epidemiology, Department of Hygiene and Prevention, Vientiane, and Savannakhet Provincial Health Department, Savannakhet, Lao PDR for their help in this study. We also thank the staff of Korea Association of Health Promotion who kindly cooperated in Korea-Laos International Collaboration on Intestinal Parasite Control in Lao PDR (2000-2004 and 2007-2011).

\section{CONFLICT OF INTEREST}

We have no conflict of interest related to this work.

\section{REFERENCES}

1. Chai JY. Intestinal flukes. In Murrell KD, Fried B eds, Food-Borne Parasitic Zoonoses: Fish and Plant-Borne Parasites. New York, USA. Springer. 2007, pp 53-115.

2. Chai JY. Human Intestinal Flukes: From Discovery to Treatment and Control. Dordrecht, The Netherlands. Springer Nature B.V. 2019, pp 169-343.

3. Chai JY. Echinostomes in humans. In Fried B, Toledo R eds, The Biology of Echinostomes. New York, USA. Springer. 2009, pp 147-183.

4. Rim HJ, Chai JY, Min DY, Cho SY, Eom KS, Hong SJ, Sohn WM, Yong TS, Deodato G, Standgaard H, Phommasack B, Yun CH, Hoang EH. Prevalence of intestinal parasite infections on a national scale among primary schoolchildren in Laos. Parasitol Res 2003; 91: 267-272.

5. Chai JY, Park JH, Han ET, Guk SM, Shin EH, Lin A, Kim JL, Sohn WM, Yong TS, Eom KS, Min DY, Hwang EH, Phommasack B, Insisiengmay, Rim HJ. Mixed infections with Opisthorchis viverri$n i$ and intestinal flukes in residents of Vientiane Municipality and Saravane Province in Laos. J Helminthol 2005; 79: 1-8.

6. Chai JY, Han ET, Guk SM, Shin EH, Sohn WM, Yong TS, Eom KS, Lee KH, Jeong HG, Ryang YS, Hoang EH, Phommasack B, Insisiendgmay B, Lee SH, Rim HJ. High prevalence of liver and intestinal fluke infections among residents of Savannakhet Province in Laos. Korean J Parasitol 2007; 45: 213-218.

7. Chai JY, Han ET, Shin EH, Sohn WM, Yong TS, Eom KS, Min DY, Um JY, Park MS, Hoang EH, Phommasack B, Insisiengmay, Lee SH, Rim HJ. High prevalence of Haplorchis taichui, Prosthodendrium molenkampi, and other helminth infections among people in Khammouane Province, Lao PDR. Korean J Parasitol 2009; 47: 243-247.
8. Chai JY, Yong TS, Eom KS, Min DY, Jeon HK, Kim TY, Jung BK, Sisabath L, Insisiengmay B, Phommasack B, Rim HJ. Hyperendemicity of Haplorchis taichui infection among riparian people in Saravane and Champasak Province, Lao PDR. Korean J Parasitol 2013; 51: 305-311.

9. Chai JY, Sohn WM, Jung BK, Yong TS, Eom KS, Min DY, Insisiengmay B, Insisiengmay S, Phommasack B, Rim HJ. Intestinal helminths recovered from humans in Xieng Khouang Province, Lao PDR with a particular note on Haplorchis pumilio infection. Korean J Parasitol 2015; 53: 439-445.

10. Sayasone S, Tesana S, Utzinger J, Hatz C, Akkhavong K, Odermatt P. Rare human infection with the trematode Echinochasmus japonicus in Lao PDR. Parasitol Int 2009; 58: 106-109.

11. Chai JY, Sohn WM, Yong TS, Eom KS, Min DY, Hoang EH, Phammasack B, Insisiengmay B, Rim HJ. Echinostome flukes recovered from humans in Khammouane Province, Lao PDR. Korean J Parasitol 2012; 50: 269-272.

12. Chai JY, Sohn WM, Cho J, Eom KS, Yong TS, Min DY, Hoang EH, Phammasack B, Insisiengmay B, Rim HJ. Echinostoma ilocanum infection in two residents of Savannakhet Province, Lao PDR. Korean J Parasitol 2018; 56: 77-81.

13. Chai JY, Chang T, Jung BK, Shin H, Sohn WM, Eom KS, Yong TS, Min DY, Phommasack B, Insisiengmay B, Rim HJ. Echinochasmus caninus $\mathrm{n}$. comb. (Trematoda: Echinostomatidae) infection in eleven riparian people in Khammouane Province, Lao PDR. Korean J Parasitol 57: 451-456.

14. Khalil M, Abaza MS. A new trematode parasite of the rat, Echinostoma aegyptiaca nov. sp. Rep Notes Public Health Lab 1924; 6: 187-189.

15. Yamaguti S. Studies on the helminth fauna of Japan. Part 27. Trematodes of mammals, II. Jpn J Med Sci (VI. Bacteriol Parasitol) 1939; 1: 131-153.

16. Chen B, Cheng Y, Chang Y, Yang W, Liu F, Lin YY. Discovery of a human case infected with Echinostoma aegyptica. Chin J Zoon 2004; 20: 717-718 (in Chinese).

17. Chen B, Li L, Xie H, Chen Z, Ouyang R, Lin Y. Morphology and characteristics of five types of Echinostomatidae in Fujian. J Pathogen Biol 2013; 8: 204-207 (in Chinese).

18. Kostadinova A. Family echinostomatidae looss, 1899. In Jones A, Bray RA, Gibson DI eds. Keys to the Trematoda. Vol. 2. London, UK. Natural History Museum. 2005, pp 9-64.

19. Sohn WM, Chai JY, Na BK, Yong TS, Eom KS, Park H, Min DY, Rim HJ. Echinostoma macrorchis in Lao PDR: metacercariae in $\mathrm{Ci}$ pangopaludina snails and adults from experimentally infected animals. Korean J Parasitol 2013; 51: 191-196.

20. Sohn WM, Na BK. Echinostoma macrorchis (Digenea: Echinostomatidae): metacercariae in Cipangopaludina chinensis malleata snails and adults from experimental rats in Korea. Korean J Parasitol 2017; 55: 541-548.

21. Azim MA. On the identification and life history of Echinostomum recurvatum von Linstow, 1873. Ann Trop Med Parasitol 1924; 24: 189-192.

22. Yamaguti S. Synopsis of Digenetic Trematodes of Vertebrates. 
Vol. I. Tokyo, Japan. Keigaku Publishing Co. 1971, pp 1-1074.

23. Fischthal JH, Kuntz RE. Some digenetic trematodes of mammals from Taiwan. Proc Helminthol Soc Wash 975; 42: 149-157.

24. Toan PQ, Luc PV, Ha PV. Some supplementary data on parasitic trematode of house rat ( $R$. flavipectus) Nghe An, Ha Tinh Provinces and describe to Centrocestus formosanus (Heterophyidae) which species the first time found from the rat in Vietnam. Tap chi Sinh Hoc 2008; 31: 9-13 (in Vietnamese).

25. Gürler AT, Bakan N. Helminths of laboratory animals in Turkey: review. J Lab Anim 2017; 1: 41-48.

26. Kanev I, Fried B, Radev V. Collar spine models in the genus Echinostoma (Trematoda: Echinostomatidae). Parasitol Res 2009; 105: 921-927. 